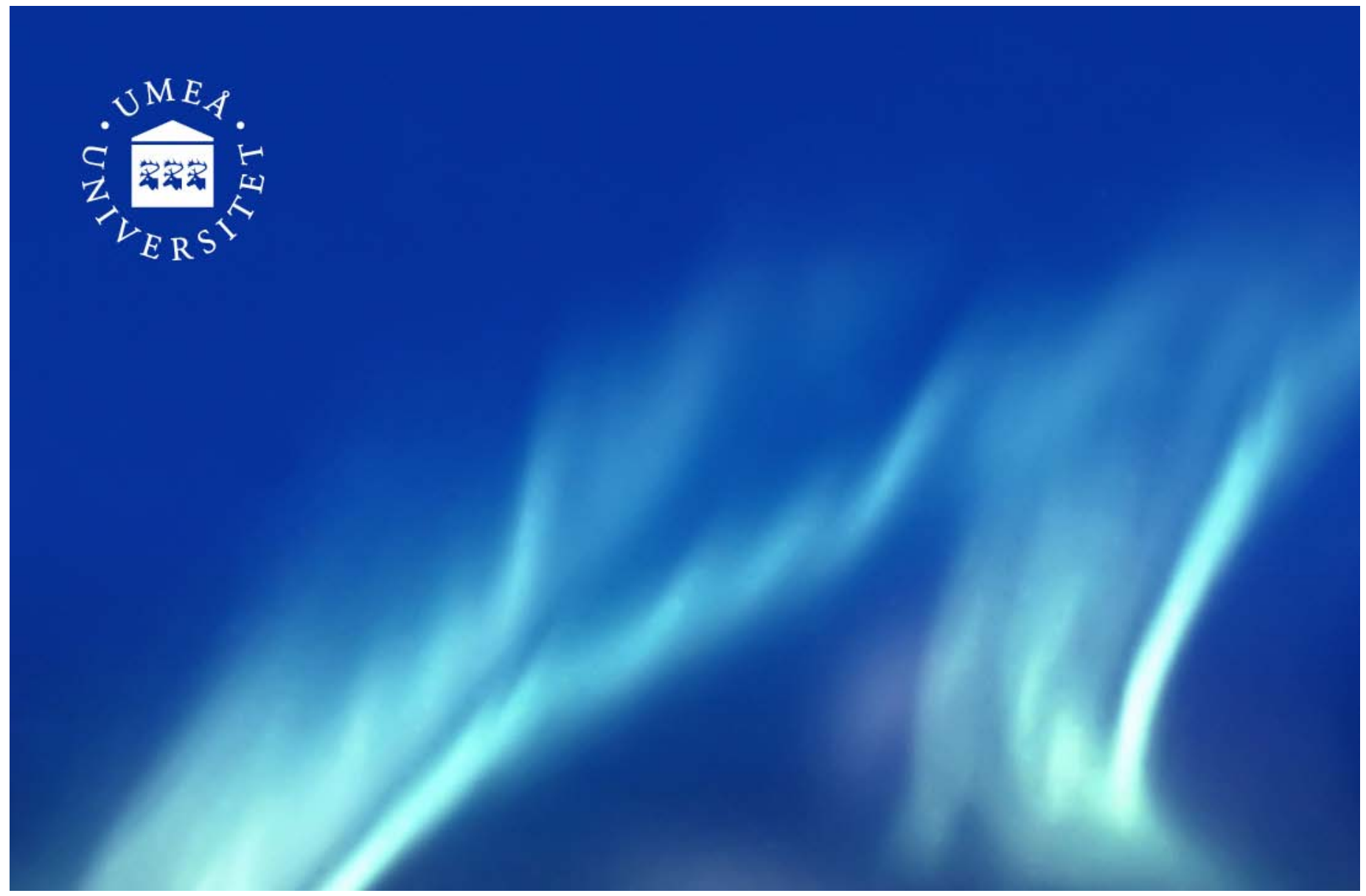

DiVA - Digitala Vetenskapliga Arkivet http://umu.diva-portal.org

This is an author produced version of a paper published in Psychopharmacology

This paper has been peer-reviewed but does not include the final publisher proof-corrections or journal pagination.

Citation for the published paper:

Erika Timby, Matts Balgård, Sigrid Nyberg, Olav Spigset, Agneta Andersson, Joanna

Porankiewicz-Asplund, Robert H. Purdy, Di Zhu, Torbjörn Bäckström and Inger Sundström Poromaa

Pharmacokinetic and behavioral effects of allopregnanolone in healthy women

Psychopharmacology, 2006, Vol. 186, Issue: 3, pp. 414-424

URL: http://dx.doi.org/10.1007/s00213-005-0148-7

Access to the published version may require subscription. Published with permission from:

\title{
Springer Verlag
}


Erika Timby ${ }^{1}$, Matts Balgård ${ }^{2}$, Sigrid Nyberg ${ }^{1}$, Olav Spigset ${ }^{3}$, Agneta Andersson ${ }^{1}$, Joanna Porankiewicz-Asplund ${ }^{4}$, Robert H. Purdy ${ }^{5}$, Di Zhu ${ }^{1}$, Torbjörn Bäckström ${ }^{1}$, Inger Sundström Poromaa $^{6}$

${ }^{1}$ Department of Clinical Science, Obstetrics and Gynecology, Umeå University, Umeå, Sweden. ${ }^{2}$ Hospital Pharmacy, University Hospital, Umeå, Sweden. ${ }^{3}$ Department of Clinical Pharmacology, Regional and University Hospital of Trondheim, Trondheim, Norway. 4 AgriSera AB, Vännäs, Sweden ${ }^{5}$ Department of Neuropharmacology, The Scripps Research Institute, La Jolla, CA, USA. ${ }^{6}$ Department Women's and Children's Health, Uppsala University, Uppsala, Sweden.

Corresponding Author: Inger Sundström Poromaa

Department Women's and Children's Health,

University Hospital, Uppsala University,

SE-751 85 Uppsala, Sweden

Phone +4618 6115764

Fax: + 4618559775

E-mail: inger.sundstrom@kbh.uu.se

Short title: Behavioral effects of allopregnanolone 
Abstract. Rationale. The behavioral effects of allopregnanolone ( $3 \alpha$-hydroxy-5 $\alpha$-pregnan20-one) in women are not known. Objective: Allopregnanolone, a neuroactive steroid secreted by the mammalian ovary, exerts its anesthetic, anxiolytic, and sedative/hypnotic effects through potentiation of $\mathrm{GABA}_{\mathrm{A}}$ receptors. The purpose of this study was to evaluate the behavioral effects of allopregnanolone in healthy women. Methods: Ten healthy women were given three increasing intravenous doses of allopregnanolone in the follicular phase of the menstrual cycle. Saccadic eye movement parameters and visual analogue scales of sedation were used to evaluate the behavioral response of allopregnanolone. Repeated blood samples for analyses of allopregnanolone were drawn throughout the study day. Results: Exogenously administered allopregnanolone decreases saccadic eye movement parameters and increases subjective ratings of sedation that correlate with increased serum concentrations of this neuroactive steroid. Conclusion: The behavioral effects of allopregnanolone are similar to that of its $5 \beta$-stereoisomer, pregnanolone ( $3 \alpha$-hydroxy-5 pregnan-20-one). Apart from fatigue and mild nausea, allopregnanolone given in a cumulative dose of $0.09 \mathrm{mg} / \mathrm{kg}$ did not have any adverse effects.

Key words: Allopregnanolone, neuroactive steroid, behavioral, saccadic eye velocity, menstrual cycle 


\section{Introduction}

Allopregnanolone ( $3 \alpha$-hydroxy-5 $\alpha$-pregnan-20-one) is an endogenous neuroactive steroid secreted by the mammalian ovary (Hodges et al. 1997; Holzbauer 1976; Ottander et al. 2005). Through binding to the $\mathrm{GABA}_{\mathrm{A}}$ receptor complexes, allopregnanolone enhances inhibitory neurotransmission (Harrison and Simmonds 1984; Majewska et al. 1986), thus exerting anxiolytic (Bitran et al. 1991, 1995; Wieland et al. 1991), sedative (Lancel et al. 1997; Sundstrom et al. 1998), and antiepileptic effects (Landgren et al. 1998). There is also evidence that allopregnanolone may mediate the effects of alcohol and benzodiazepines in both experimental animals (Morrow et al. 1999, 2001) and humans (Torres and Ortega 2003; however, see Nyberg et al. 2005). The binding site(s) of allopregnanolone to the $\mathrm{GABA}_{\mathrm{A}}$ receptor is unknown but differs from those of benzodiazepines, barbiturates, and picrotoxin (Gee et al. 1995; Lan et al. 1991).

Although allopregnanolone can be synthesized de novo in the central nervous system (CNS) from cholesterol (Stoffel-Wagner 2001), it is conceivable that plasma allopregnanolone in women predominantly originates from the corpus luteum (Backstrom et al. 1986; Ottander et al. 2005). Plasma concentrations of allopregnanolone temporally follow those of progesterone, and levels of approximately $6-10 \mathrm{nmol} \mathrm{L}-1$ have been found in the mid-luteal phase of the menstrual cycle (Genazzani et al. 1998; Wang et al. 1996), and during thirdtrimester pregnancy, allopregnanolone levels up to $150 \mathrm{nmol} \mathrm{L}-1$ have been found in maternal blood and umbilical cord blood (Hill et al. 2000, 2001; Luisi et al. 2000; Parizek et al. 2005).

Oral administration of micronized progesterone, which results in variable serum levels of allopregnanolone (Freeman et al. 1993; de Lignieres et al. 1995), is unable to relieve symptoms of anxiety and depression in women with severe premenstrual syndrome (Vanselow et al. 1996; Wyatt et al. 2001). In cognitive studies, such a single dose in those women, where high serum levels of allopregnanolone were obtained, produced increased fatigue, confusion, and poor concentration, symptoms similar to those encountered among women with premenstrual dysphoric disorder (Freeman et al. 1993). For postmenopausal women treated with vaginal progesterone, negative mood symptoms occurred at serum concentrations of allopregnanolone similar to endogenous luteal phase levels, whereas lower or higher concentrations had no significant effect on mood (Andreen et al. 2005). Although the role of allopregnanolone thus far is unclear, numerous studies have reported altered peripheral levels of allopregnanolone in psychiatric mood disorders such as premenstrual 
dysphoric disorder (Bicikova et al. 1998; Girdler et al. 2001; Monteleone et al. 2000; Rapkin et al. 1997; however, see Schmidt et al. 1994; Sundstrom and Backstrom 1998), major depression (Romeo et al. 1998), and anxiety disorders (Strohle et al. 2002).

Prior studies in laboratory animals have indicated that acute administration of allopregnanolone is anxiolytic and soporific (Bitran et al. 1991, 1999; Lancel et al. 1997; Wieland et al. 1991). However, whether allopregnanolone is intrinsically rewarding or aversive is thus far unclear, since existing evidence is contradictory. For example, in low doses, allopregnanolone induces conditioned place aversion in male rats, indicating innate negative reinforcing effects (Beauchamp et al. 2000), whereas a conditioned preference was evident at higher doses of allopregnanolone in male mice, indicating positive reinforcing effects (Finn et al. 1997). Furthermore, while it is established that acute injections of progesterone and allopregnanolone are reliably anxiolytic within an hour, a few days of high neurosteroid levels can increase anxiety and modulate $\mathrm{GABA}_{\mathrm{A}}$ receptor subunit expression and function (Friedman et al. 1993; Gulinello et al. 2001; Yu et al. 1996a, b).

The sedative effect of allopregnanolone can be evaluated by use of saccadic eye movement (SEM) measurements. A saccade is a rapid, jump-like movement of the eye from one fixation point to another, used by the eye in order to change the focus of the fovea. Maximal saccadic eye velocity (SEV) has a large variation of 350-600 deg/s between subjects (Hommer et al. 1986; Sundstrom and Backstrom 1998), but is stable within subjects, both within a testing period and between testings (Gentles and Thomas 1971; Glue et al. 1991; Hommer et al. 1986; Roy-Byrne et al. 1990; Sundstrom and Backstrom 1998). Once a saccade has started, it is generally believed to be outside conscious control and not subjected to motivational influences (Gentles and Thomas 1971), and therefore, SEV is considered to provide an objective and sensitive measure of sedation. SEV has previously been shown to be reduced in a dose-dependent manner by benzodiazepines, pregnanolone (the $5 \beta$-stereoisomer of allopregnanolone, 3 $\alpha$-hydroxy-5 $\beta$-pregnan-20-one), and alcohol (Hommer et al. 1986; Nyberg et al. 2004; Sundstrom et al. 1997, 1998). Furthermore, benzodiazepine- and pregnanolone-induced increases in self-ratings of sedation, which is another pharmacological action of these compounds, are highly correlated with reduction in SEV (Hommer et al. 1986; Sundstrom et al. 1998).

Knowledge of allopregnanolone's effects in humans is very limited. Since allopregnanolone appears to be involved in a number of mood disorders in women, further studies of its effects need to be undertaken. The aim of the current study was to determine the pharmacokinetics of allopregnanolone and its effect on saccadic eye movement parameters and self-rated sedation 
in healthy women. A secondary aim of the study was to evaluate a new egg-yolk antisera for allopregnanolone analyses.

\section{Materials and methods}

Subjects

Thirteen healthy women between the ages of 18 and 40, with regular menstrual cycles (29.4 \pm 0.8 days), were screened for inclusion in the study. They were recruited through advertisement in the local newspaper. Of these, 10 women were selected. The exclusion criteria were treatment with any steroid compound (including oral contraceptives and hormonal intrauterine devices) for at least 6 months prior to enrollment in the study, treatment with benzodiazepines or other psychotropic drugs within the last 3 months preceding inclusion, and treatment with any daily over-the counter drug during the last 4 weeks before inclusion. Women planning to become pregnant were excluded. Further exclusion criteria were any current or previous somatic disease, any mental disorder, including PMDD, during the last 6 months, or a history of drug abuse. The presence of psychiatric disorders was evaluated using a structured psychiatric interview, Primary Care Evaluation of Mental Disorders, which has been validated for use in primary care settings and conforms to the criteria in Diagnostic and Statistical Manual of Mental Disorders, 4th Edition (Spitzer et al. 1994). Before inclusion, physical and gynecological examinations were performed, as well as routine urine and blood chemistry screens. All subjects had negative pregnancy tests and normal blood chemistry screens. No night work or jet-lag travels were allowed during the week before the study day. The women gave written informed consent prior to inclusion in the study. The study procedures were in accordance with ethical standards for human experimentation, established by the Declaration of Helsinki of 1975, revised in 1983. The Research Ethics Committee, University of Umeå, and the Medical Products Agency of Sweden approved the study.

\section{Study protocol}

Testing was carried out in a gynecological outpatient department. Allopregnanolone was administered in the follicular phase (days 5-10 of the menstrual cycle). No subjects consumed alcohol $24 \mathrm{~h}$ prior to testing. Caffeine and tobacco use was restricted throughout 
the study day. Subjects arrived at 8:00 a.m. An intravenous cannula was inserted in each forearm, and blood samples were taken for baseline levels of allopregnanolone in serum. To establish baseline, three sets of SEV measurements and visual analogue ratings of sedation and intoxication were made, with 5-min rest in between. Thereafter, at 9:00 p.m., three intravenous injections of allopregnanolone were given at 30-min intervals, using doses of $0.015,0.03$, and $0.045 \mathrm{mg} / \mathrm{kg}$, thus giving a cumulative dose of $0.09 \mathrm{mg} / \mathrm{kg}$. Each injection was given more than 30 s. The Umeå University Hospital Pharmacy prepared the experimental medications. Intravenous allopregnanolone solution was formulated with purified allopregnanolone, UC1009 (Umecrine AB, Box 7984, 90719 Umeå, Sweden) 15 mg dissolved in $100 \mathrm{ml}$ albumin solution (Pharmacia, Stockholm, Sweden, $200 \mathrm{mg} / \mathrm{ml}$ ) using an ultrasound bath. The solution contained $0.126 \pm 0.003 \mathrm{mg} / \mathrm{ml}$ (mean $\pm \mathrm{SEM}$ ) allopregnanolone $(n=9)$. The allopregnanolone concentration of each batch of solution was determined using HPLC and UV absorbance (Turkmen et al. 2004). After each allopregnanolone injection, SEV recordings and visual analogue ratings were made at 5, 13, and $21 \mathrm{~min}$, respectively. At the time of SEV measurements, plasma for measuring allopregnanolone levels was drawn from the arm contralateral to that used for drug administration. Additional SEV recordings and blood sampling were performed at 95, 105, 115, 150, and $330 \mathrm{~min}$. Subjects were allowed to ambulate in the gynecologic ward and the hospital area after the 150-min SEV recording and blood sampling.

Blood samples were also drawn at 600 and $780 \mathrm{~min}$ (the last blood sample $13 \mathrm{~h}$ after the first allopregnanolone injection, at 10:00 p.m.).

Saccadic eye movements

Saccadic eye velocity (SEV) was measured using electrooculography (EOG) with the CSGAAS5 system, fully documented elsewhere (Marshall et al. 1985; Marshall and Richens 1989). The test was performed in a quiet, semi-lit room with the patient sitting in a comfortable chair. Head movements were prevented by supporting the subject's head with a pillow. EEG cup electrodes (Synetics AB, Stockholm, Sweden) with a small amount of electrode gel (Elefix, Nihon Kohden) were used. After the skin had been exfoliated with Skinpure cream (Nihon Kohden), the electrodes were placed $1 \mathrm{~cm}$ lateral of the outer canthus of both eyes, with one common electrode in the center of the forehead. Electrode impedance was measured and confirmed to be less than $5 \mathrm{k} \Omega$. The subject was instructed to watch an array of light-emitting diodes (LEDs) placed at eye-level, $67 \mathrm{~cm}$ from the glabella. The target 
for the eye movements was an illuminated LED. The subject was asked to look at the illuminated LED and to move her eyes to the next target (the next illuminated LED), as that LED was turned off, and the next one in the array was lit. Subjects were instructed not to anticipate targets.

The target movements took place at 1.5 -s intervals. A fixed, nonrandom sequence of $4 \times 24$ targets producing target steps of $10^{\circ}, 20^{\circ}, 30$, and $40^{\circ}$ was displayed with a brief rest in between. The first four of these 24 target steps of each session were not included in the subsequent analyses in order to allow the subject to adjust to the procedure. The EOG was DC amplified and low-pass filtered $(-3 \mathrm{~dB}$ at $50 \mathrm{~Hz})$ before being digitized to 12-bit resolution at a sampling frequency of $250 \mathrm{~Hz}$. A personal computer controlled the target movements and digitized the waveform using an analogue-digital converter. The 80 individual EOGs, resulting from the $4 \times 20$ target steps, were stored and analyzed off-line according to the method of Marshall and Richens (1989). First, the digitized data from each target displacement were processed to locate saccades. To avoid preemptive saccades and blinking artifacts, only saccades initiated 50 to $400 \mathrm{~ms}$ after target movements were included. Also, to be considered a saccade, the recorded eye movement had to display a velocity of more than $100 \mathrm{deg} / \mathrm{s}$. Second, each saccade was analyzed to determine the size of the saccade in degrees, the peak saccadic velocity, and latency from target movement to onset of saccade. Saccade accuracy was determined by comparing the actual eye position at the end of the saccade with the attempted target. SEV was further processed by plotting a velocity-saccade size curve, known as the main sequence (Baloh et al. 1975). The relationship between saccade size and peak velocity is important since it remains constant even when voluntary control of saccades is attempted. The main sequence was fitted by a quadratic equation to the peak velocity data using the calculated saccade angle as the independent variable. The influence of outliers in the data was minimized by carrying out the fitting procedure twice and weighing the second fit with the inverse of the square of the residuals from the first fit. The values of peak velocity for $10^{\circ}, 20^{\circ}, 30^{\circ}$ and $40^{\circ}$ saccades were then calculated by interpolation. Saccades with amplitudes of $30^{\circ}$ were chosen for further analyses as SEV reaches a maximum at approximately $30-35^{\circ}$ of angular movement (Baloh et al. 1975).

\section{Visual analogue ratings}

A visual analogue scale (VAS) was used to rate sedation and subjective feelings of alcohollike intoxication (McCormack et al. 1988). The scale measured from 0 to $10 \mathrm{~cm}$, where 0 equaled complete absence of sleepiness/feelings of intoxication and 10 represented falling 
asleep/feelings of heavy intoxication. Subjective ratings of sedation and intoxication were made at baseline, after each of the saccadic eye measurements, and at 600 and $780 \mathrm{~min}$.

Assays of Allopregnanolone

\section{Extraction}

Allopregnanolone was measured by radioimmunoassay (RIA) after diethylether extraction and celite chromatographic purification of samples. Serum or plasma $(0.2-0.4 \mathrm{~mL})$ was pipetted into a cylindrical flat bottom glass vial of $20 \mathrm{~mL}$ volume, whereafter water $(0.5 \mathrm{~mL})$ and diethyl ether $(3.0 \mathrm{~mL})$ were added. The samples were then allowed to stand on an orbital shaker for $10 \mathrm{~min}$. Following the liquid-liquid extraction, the vials were transferred into an ethanol/dry ice bath. The water phase was frozen, and the ether phase was decanted and evaporated under a stream of nitrogen gas.

\section{Celite chromatography}

The evaporated sample was dissolved in $1.0 \mathrm{ml}$ isooctane (Merck) saturated with ethylene glycol (J.T. Baker), before application to the column. Celite column chromatography was performed as follows. Glass columns $(50 \mathrm{~mm} \times 5 \mathrm{~mm}$ i.d.) were tightly packed with a mixture of Celite (Mansville,Denver, CO, USA, heated to $600^{\circ} \mathrm{C}$ overnight) and propylene glycol (Merck), w/v, 1/1. Isooctane $(10 \mathrm{ml})$ was percolated through the columns before sample applications. The sample was applied, followed successively by a 1.0-ml isooctane wash, 1.5 $\mathrm{ml}$ isooctane to elute $5 \alpha$ - and $5 \beta$-dihydroprogesterone, $4 \mathrm{ml}$ isooctane to elute progesterone, an additional $4 \mathrm{ml}$ isooctane to elute allopregnanolone, and in the next $4.0 \mathrm{ml}$ isooctane to

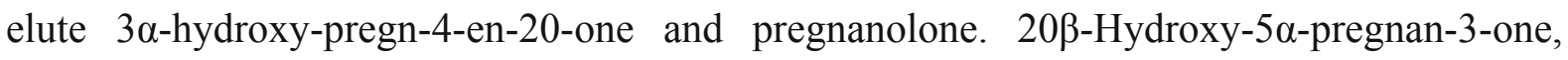
which cross-reacts with the rabbit antisera, is not eluted with isooctane.

The allopregnanolone-containing fraction was evaporated under nitrogen. Recovery was determined for each assay using 300-500 cpm of tritium-labeled allopregnanolone, [9,11,12$3 \mathrm{H}(\mathrm{N})$ ]-5 $\alpha$-pregnan-3 $\alpha$-ol-20-one (Perkin-Elmer Life Sciences, Boston, USA) added to a plasma sample before extraction and by measuring the amount recovered after chromatography. The recovery of allopregnanolone averaged $78 \%$, and the results are compensated for recovery.

Radioimmunoassay 
All samples were analyzed using a polyclonal rabbit antiserum (Purdy et al. 1990). For the evaluation of the new egg-yolk antisera (Agrisera AB, Vannas, Sweden), some of the samples were analyzed using both the rabbit antisera and the egg-yolk antisera, $n=77$. Additionally, for evaluation purposes, both antisera were used to analyze 18 follicular phase samples ( 8 samples from the current study and 10 samples from healthy controls, used as internal standard).

The Agrisera antibody is an egg-yolk IgY antibody, immunized in the hen. Both these

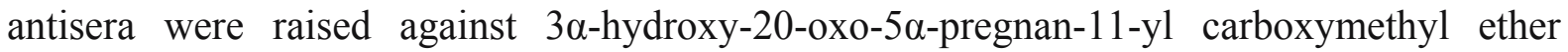
coupled to bovine serum albumin, (Purdy et al. 1990). The cross-reactivity of the antibodies is shown in Table 1. The standard curve was established by preparing duplicate tubes containing eight concentrations of unlabeled allopregnanolone to give a range from 0 to 5,000 pg. Rabbit antiserum was used in a dilution of 1/5,000, while the egg-yoke IgY antibody was used in a dilution of 1/1,000; otherwise, the antibody solutions were prepared in the same way as described below.

The antibody solutions were prepared using [11,12]3Hallopregnanolone, $3 \times 106 \mathrm{cpm} / 32 \mathrm{ml}$ solution containing $65 \mathrm{mM}$ boric acid (Merck) buffer, $\mathrm{pH}=8.0$, bovine serum albumin 100 $\mathrm{mg} / \mathrm{ml}$ (Sigma, St Louis, USA), human gamma globulin solution $20 \mathrm{mg} / \mathrm{ml}$ (Octapharma, Sweden) and antibody in milliliter ratio, hen antibody solution: 30:1:1:0.032, rabbit antisera solution: 30:1:1:0.006. The solution was allowed to equilibrate overnight at $8^{\circ} \mathrm{C}$. Antibody solution $(200 \mu \mathrm{l})$ was added to all standard and sample tubes, and the mixture allowed to stand overnight at $8^{\circ} \mathrm{C}$. After the addition of $200 \mu$ saturated ammonium sulfate, each tube was again mixed and centrifuged at 20,000 RPM for $20 \mathrm{~min}$. Thereafter, the supernatant was aliquoted into a counting vial and diluted with $3.0 \mathrm{ml}$ Optiphase scintillation medium (Wallac, Finland). The samples were counted in a RackBeta (Wallac) scintillation counter. The sensitivity of the assays was $25 \mathrm{pg}$, with an intraassay coefficient of variation for allopregnanolone of $6.5 \%$ and an interassay coefficient of variation of $8.5 \%$.

Pharmacokinetic and statistical analyses

Before the pharmacokinetic calculations were carried out, the baseline allopregnanolone concentration $(\mathrm{C} 0)$ was subtracted from the measured values obtained 5-780 min later. Only the net concentrations were used for the pharmacokinetic analyses. Baseline concentrations were less than $1 \%$ of the maximum concentration at the same sampling occasion. Pharmacokinetic parameters were calculated by means of the Kinetica version 4.3 program 
(InnaPhase Corporation, Philadelphia, PA, USA), using a two-compartment model. The parameter estimates describing the elimination phase (terminal phase) slopes of the logconcentration of allopregnanolone $(\lambda z)$ were calculated using the concentrations from 330 to $780 \mathrm{~min}$ after the first dosage, as this always gave the best-fit regression lines. The parameter estimates describing the distribution phase slopes of the log-concentration of allopregnanolone $(\lambda 1)$ were calculated using the best-fit regression line with more than three concentration/time observations included, counted backwards from the measurement after $150 \mathrm{~min}$. Half-lives in the distribution phase $(\mathrm{t} 1 / 2,1)$ and the elimination phase $(\mathrm{t} 1 / 2, \mathrm{z})$ were calculated as $\ln 2 / \lambda 1$ and $\ln 2 / \lambda z$, respectively. Areas under the curve (AUC) were calculated using a mixed log-linear method with extrapolation to infinity.

The mean extrapolated AUC was 5.2\% (range 0.6-10.3\%) of the total AUC. Clearances (CL) were calculated as dose/AUC. The volumes of distribution in the elimination phase (Vz) were calculated as CL/ $\lambda z$. The volumes of distribution at steady state (Vss) were calculated as Dose $\times$ MRT/AUC. In this equation, MRT is mean residence time and is calculated as AUMC/AUC, in which AUMC is the area under the concentration-time product vs time curve from zero to infinity.

Saccadic eye movement parameters and self-rating scores were calculated as delta scores (difference from baseline at each time-point). The saccadic eye movement parameters were analyzed by one-way ANOVA (analysis of variance) with repeated measures using timepoint as within-subjects factor. Post hoc tests for each time-point were obtained by Tukey Honestly Significance Test. Correlations between allopregnanolone levels, the saccadic eye movement parameters, and the subjective scores were made by partial correlation. The SPSS statistical package was used for the analyses. P values of less than 0.05 were considered to be statistically significant.

\section{Results}

Demographic data of the study group are given in Table 2. For technical reasons, saccadic eye movements after the third injection and throughout the remaining test session could not be assessed in two women. Saccadic eye movements are missing for three subjects at the 330min measurements. Pharmacokinetic parameters for allopregnanolone are summarized in Table 3. The serum allopregnanolone concentration-time relationships are shown in Fig. 1. Allopregnanolone induces a significant reduction in $\operatorname{SEV}(F(14,9)=10.09, p<0.001)$, saccade acceleration $(F(14,9)=8.15, p<0.001)$, as well as a significant change in saccade deceleration 
$(F(14,9)=10.67, p<0.001)$ and self-rated scores of sedation $(F(16,9)=11.61, p<0.001)$ (Fig. 2$)$. Saccade accuracy $(\mathrm{F}(14,9)=3.25, \mathrm{p}<0.001)$ was also significantly deteriorated, whereas saccade latency $(F(14,9)=1.68)$ was unaffected by the allopregnanolone injections (Fig. 2). According to the post hoc analyses, significant responses in SEV, saccade acceleration, and saccade deceleration were noted after the $0.03 \mathrm{mg} / \mathrm{kg}$ dose of allopregnanolone, whereas saccade accuracy and sedation scores were not affected until the $0.045 \mathrm{mg} / \mathrm{kg}$ dose. The effect of allopregnanolone on SEV, saccade acceleration, and saccade deceleration lasted 45 min after the final dose (Fig. 2). Saccade accuracy and self-rated sedation were affected until $55 \mathrm{~min}$ after the $0.045 \mathrm{mg} / \mathrm{kg}$ dose, Fig. 2. The maximum decrease in SEV following allopregnanolone injections was $13.2 \% \pm 2.7$ (mean \pm SEM).

Allopregnanolone serum concentrations were significantly correlated with SEV $(r=-0.48$, $\mathrm{p}<0.001)$, saccade acceleration $(\mathrm{r}=-0.44, \mathrm{p}<0.001)$, saccade deceleration $(\mathrm{r}=-0.50, \mathrm{p}<0.001)$, saccade accuracy $(r=-0.41, p<0.001)$, and subjective scores of sedation $(r=-0.45$, $\mathrm{p}<0.001)$. Three women reported mild feelings of alcohol-like intoxication during the test session. Three women experienced mild nausea following the allopregnanolone injections and one woman reported flushing. Twenty-four hours after the administration of allopregnanolone, one woman reported an anxiety attack. Four of the subjects were tobacco users. Although the tobacco users were abstaining from nicotine during the test session, there was no difference in saccadic eye movement response or subjective response to allopregnanolone between these subjects and the remaining group (data not shown). However, three of four tobacco users reported adverse effects during and after the test session, whereas three of six nonusers reported any side effects.

Allopregnanolone concentrations $(\mathrm{nmol} \mathrm{L}-1)$ were measured using the two different antibodies in 77 serum samples. After celite chromatography separation, the serum samples were assayed with both rabbit antisera (Purdy et al. 1990) and a hen IgY antibody (Agrisera). The result of the analysis of allopregnanolone, using these two antibodies, is shown in Fig. 3. The correlation coefficient was $\mathrm{r}=0.962, \mathrm{p}<0.001$. The baseline concentrations obtained during the follicular phase of the menstrual cycle $(n=18$, mean \pm SEM) were $0.429 \pm 0.031$ nmol L-1 (rabbit antisera) and $0.449 \pm 0.039 \mathrm{nmol} \mathrm{L}-1$ (egg-yolk antisera). The baseline follicular phase values were not different between the two antisera.

\section{Discussion}


The main finding of the present study is that exogenously administered allopregnanolone decreases saccadic eye movement parameters and increases subjective ratings of sedation that correlate with increased serum concentrations of this neuroactive steroid.

Prior studies with exogenous allopregnanolone administration in humans are limited. In one study, allopregnanolone was given as a vaginal gel in a dose of $90 \mathrm{mg}$ to 13 postmenopausal women on oral estrogen therapy. Adverse effects were few (mainly mastalgia) and interpreted as related to estradiol administration (Navarro et al. 2003). According to endometrial biopsies, their data suggested that allopregnanolone had no secretory action on the endometrium; however, 5 of 13 patients reported bleeding after the allopregnanolone addition to estradiol treatment. It should be noted that allopregnanolone is rapidly metabolized to 5 $\alpha$-pregnane-3,20-dione, which is a potent progestin (Milewich et al. 1979), which in turn could explain the endometrial shedding. Pregnanolone, the $5 \beta$-epimer of allopregnanolone, which is not metabolized to an active progestin, has previously been investigated in humans, predominantly for the induction of anesthesia (Carl et al. 1990, 1994). The sedative effects of pregnanolone have been studied across different hormonal conditions, such as the menstrual cycle and during hormone replacement therapy (Sundstrom et al. 1998; Wihlback et al. 2001, 2005), and depend on endogenous concentrations of neuroactive steroids. Pharmacokinetics of pregnanolone, however, appear not to be influenced by the hormonal changes during the menstrual cycle (Sundstrom et al. 1999). Pregnanolone and allopregnanolone have similar pharmacokinetic and behavioral properties in rats, although allopregnanolone appears to be more potent in some studies (Norberg et al. 1987; Wang et al. 1995; Zhu et al. 2001).

The current study demonstrates that allopregnanolone has a distribution half-life of $43.9 \mathrm{~min}$, and a clearance volume of $32.6 \mathrm{ml} \mathrm{min-1} \mathrm{kg-1}$. This finding might indicate that allopregnanolone has a slightly longer distribution half-life than the previously reported halflife of the pregnanolone-albumin solution $(31.8 \mathrm{~min}$ ) (Sundstrom et al.1999). Also, the clearance volume was smaller compared to that previously reported for pregnanolone $(61.0$ $\mathrm{ml} \mathrm{min-1} \mathrm{kg-1)} \mathrm{(Sundstrom} \mathrm{et} \mathrm{al.} \mathrm{1999).} \mathrm{Presumably,} \mathrm{this} \mathrm{could} \mathrm{suggest} \mathrm{that}$ allopregnanolone is redistributed and metabolized at slower rates than pregnanolone. However, direct comparative studies are needed to verify possible differences in pharmacokinetic properties between the two stereoisomers.

It has been demonstrated in this study that allopregnanolone given intravenously in a cumulative dose of $0.09 \mathrm{mg} / \mathrm{kg}$ significantly affects parameters of saccadic eye movements, as objective measures of sedation and self-reported sedation. We have previously used a 
cumulative dose of $0.18 \mathrm{mg} / \mathrm{kg}$ pregnanolone in a similar study to evaluate the sedative effects of the compound. In the present study, the $0.09 \mathrm{mg} / \mathrm{kg}$ dose of allopregnanolone induced a maximum percent decrease in SEV of $13.2 \%$. The maximum percent decrease in SEV following a cumulative dose of $0.18 \mathrm{mg} / \mathrm{kg}$ of pregnanolone was approximately $21 \%$ (Sundstrom et al. 1998). Our findings could indicate that allopregnanolone might be more potent than pregnanolone in humans, which would be consistent with those animal studies suggesting that allopregnanolone is more potent than its $5 \beta$-stereoisomer (Norberg et al. 1987; Wang et al. 1995; Zhu et al. 2001).

The cumulative dose in this study, $0.09 \mathrm{mg} / \mathrm{kg}$ of allopregnanolone, resulted in a maximum serum concentration of approximately $70 \mathrm{nmol} \mathrm{L}-1$. This concentration is similar to that found during third-trimester pregnancy (Hill et al. 2000, 2001; Luisi et al. 2000; Parizek et al. 2005); it produced significant effects in objective and subjective measures of sedation. Given the pronounced effect of acutely administered allopregnanolone found in this study, it is conceivable that a gradual tolerance to the sedative effects of allopregnanolone occurs during pregnancy. This hypothesis is supported by the finding that acute tolerance to the anesthetic effect of allopregnanolone in male rats, evaluated using the silent second threshold to anesthesia, rapidly develops during the course of the experiment (Zhu et al. 2004). Again, the hypothesis of a gradual development of tolerance to allopregnanolone during pregnancy needs to be evaluated in detail before any definitive conclusions can be drawn.

Adverse effects of allopregnanolone in the present study were usually mild, including three subjects reporting nausea, three subjects reporting feelings of intoxication, and one subject reporting flushing following the injection. However, $24 \mathrm{~h}$ following the allopregnanolone injection, one subject reported an anxiety attack, which lasted for a couple of hours. Some of the adverse effects could be due to the fact that four of the subjects during the test session were abstaining from their regular tobacco use. The behavioural and progestational responses, as well as safety aspects, of higher doses of allopregnanolone remain to be evaluated.

There are a number of limitations of the current study; this is why the study results must be interpreted with caution. The major limitation is that no control group was included in the study, whereby possible effects of general fatigue during the session cannot be distinguished from the allopregnanolone effect. However, the parameters most likely to be affected by this limitation are the subjective measures. By plotting main sequences of SEVand saccadic deceleration, we are able to control for voluntary attempts to slow down the saccadic velocity and saccade deceleration. Furthermore, SEV is considered stable within subjects both within 
a testing session and between sessions, and learning effects appear not to occur (Hommer et al. 1986; Sundström et al. 1998; Sundström and Backstrom 1998).

Another potential limitation of the present study for the interpretation of the behavioral effects of allopregnanolone is that endogenous progestin levels of $5 \alpha$-pregnanedione (the principal metabolite of allopregnanolone) might interfere with the behavioral variables. However, fluctuations in the endogenous levels of $5 \alpha$-pregnanedione and progesterone are only likely to minimally influence the allopregnanolone concentrations in our subjects, as tests were scheduled in the early follicular phase. Furthermore, a limitation for the interpretation of pharmacokinetic effects of allopregnanolone was that blood sampling during the initial phase of the experiment was too sparse to allow a three-compartment modeling for pharmacokinetics of allopregnanolone.

The new antibody produced in the hen can adequately measure allopregnanolone concentrations after its intravenous administration. This antibody has a slightly different cross-reactivity compared to the polyclonal antibody produced in the rabbit (Purdy et al. 1990). The antigen for both antisera was the BSA conjugate of the same hapten. The hen antibody has a higher cross-reactivity for $3 \beta$-hydroxy-5 $\alpha$-pregnan-20-one, pregnenolone, and pregnanolone, but a lower cross-reactivity for 3 $\alpha$-hydroxypregn-4-en-20-one, 5 $\beta$-pregnane-

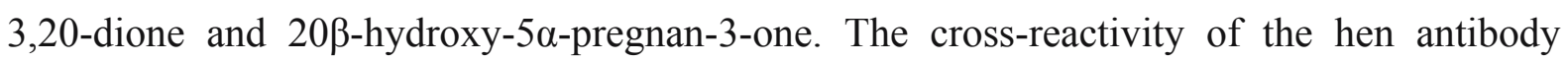
indicates that a preceding chromatographic step is necessary. In Materials and methods, we describe an effective chromatographic procedure, and in this study, we compared the results by RIA with both antisera. As can be seen in Fig. 1, there is a good correlation between the concentrations from the two assays. The regression line is very close to ideal and passes the $y$-axis close to the origin. Also, the allopregnanolone serum concentrations obtained with both antibodies give similar results.

The baseline follicular-phase allopregnanolone serum concentrations obtained in this study are similar or slightly lower compared to earlier reported concentrations by the use of chromatography and RIA (Bicikova et al. 2000; Genazzani et al. 1998; Monteleone et al. 2000; Schmidt et al. 1994; Wang et al. 1996), as well as by the use of gas chromatography/mass spectrometry (GC/MS) (Epperson et al. 2002; Strohle et al. 2002). The concentrations in the present paper are, however, higher than the concentrations reported by Pearson Murphy and Allison (2000), where very low levels of allopregnanolone were found in both the follicular and luteal phases. The reason for this discrepancy may be due to their very low recovery (mean 35\%) after extraction and HPLC, which may not have been fully compensated. 
In conclusion, the present study demonstrates that allopregnanolone can safely be given intravenously in low doses to women. Its behavioral effects are similar to those previously reported for pregnanolone. Further studies on the effects of and the sensitivity to allopregnanolone in subjects with psychiatric and hormonal disorders are crucial for the understanding of the neuroactive role of allopregnanolone.

Acknowledgements

This study was supported by grants from the

Swedish Research Council, medicine proj. 4X-11198, EU structural

fund objective 1 program, the Astrid Karlsson Foundation, and the

Tore Nilsson Foundation. 


\section{References}

Andreen L, Sundstrom-Poromaa I, Bixo M, Andersson A, Nyberg S, Backstrom T (2005) Relationship between allopregnanolone and negative mood in postmenopausal women taking sequential hormone replacement therapy with vaginal progesterone. Psychoneuroendocrinology 30:212-224

Backstrom T, Andersson A, Baird DT, Selstam G (1986) The human corpus luteum secretes 5 alpha-pregnane3,20-dione. Acta Endocrinol (Copenh) 111:116-121

Baloh RW, Sills AW, Kumley WE, Honrubia V (1975) Quantitative measurement of saccade amplitude, duration, and velocity. Neurology 25:1065-1070

Beauchamp MH, Ormerod BK, Jhamandas K, Boegman RJ, Beninger RJ (2000) Neurosteroids and reward: allopregnanolone produces a conditioned place aversion in rats. Pharmacol Biochem Behav 67:29-35

Bicikova M, Dibbelt L, Hill M, Hampl R, Starka L (1998) Allopregnanolone in women with premenstrual syndrome. Horm Metab Res 30:227-230

Bicikova M, Tallova J, Hill M, Krausova Z, Hampl R (2000) Serum concentrations of some neuroactive steroids in women suffering from mixed anxiety-depressive disorder. Neurochem Res 25:1623-1627

Bitran D, Hilvers RJ, Kellogg CK (1991) Anxiolytic effects of 3 alpha-hydroxy-5 alpha[beta]-pregnan-20-one: endogenous metabolites of progesterone that are active at the GABAA receptor. Brain Res 561:157-161

Bitran D, Shiekh M, McLeod M (1995) Anxiolytic effect of progesterone is mediated by the neurosteroid allopregnanolone at brain GABAA receptors. J Neuroendocrinol 7:171-177

Bitran D, Dugan M, Renda P, Ellis R, Foley M (1999) Anxiolytic effects of the neuroactive steroid pregnanolone (3 alpha-OH-5 beta-pregnan-20-one) after microinjection in the dorsal hippocampus and lateral septum. Brain Res 850:217-224

Carl P, Hogskilde S, Nielsen JW, Sorensen MB, Lindholm M, Karlen B, Backstrom T (1990) Pregnanolone emulsion. A preliminary pharmacokinetic and pharmacodynamic study of a new intravenous anaesthetic agent. Anaesthesia 45:189-197

Carl P, Hogskilde S, Lang-Jensen T, Bach V, Jacobsen J, Sorensen MB, Gralls M, Widlund L (1994)

Pharmacokinetics and pharmacodynamics of eltanolone (pregnanolone), a new steroid intravenous anaesthetic, in humans. Acta Anaesthesiol Scand 38:734-741

de Lignieres B, Dennerstein L, Backstrom T (1995) Influence of route of administration on progesterone metabolism. Maturitas 21:251-257

Epperson CN, Haga K, Mason GF, Sellers E, Gueorguieva R, Zhang W, Weiss E, Rothman DL, Krystal JH (2002) Cortical gammaaminobutyric acid levels across the menstrual cycle in healthy women and those with premenstrual dysphoric disorder: a proton magnetic resonance spectroscopy study. Arch Gen Psychiatry 59:851-858

Finn DA, Phillips TJ, Okorn DM, Chester JA, Cunningham CL (1997) Rewarding effect of the neuroactive steroid 3 alphahydroxy-5 alpha-pregnan-20-one in mice. Pharmacol Biochem Behav 56:261-264

Freeman EW, Purdy RH, Coutifaris C, Rickels K, Paul SM (1993) Anxiolytic metabolites of progesterone: correlation with mood and performance measures following oral progesterone administration to healthy female volunteers. Neuroendocrinology 58: 478-484 
Friedman L, Gibbs TT, Farb DH (1993) Gamma-aminobutyric acidA receptor regulation: chronic treatment with pregnanolone uncouples allosteric interactions between steroid and benzodiazepine recognition sites. Mol Pharmacol 44:191-197

Gee KW, McCauley LD, Lan NC (1995) A putative receptor for neurosteroids on the GABAA receptor complex: the pharmacological properties and therapeutic potential of epalons. Crit Rev Neurobiol 9:207-227

Genazzani AR, Petraglia F, Bernardi F, Casarosa E, Salvestroni C, Tonetti A, Nappi RE, Luisi S, Palumbo M, Purdy RH, Luisi M (1998) Circulating levels of allopregnanolone in humans: gender, age, and endocrine influences. J Clin Endocrinol Metab 83:2099-2103

Gentles W, Thomas EL (1971) Commentary. Effect of benzodiazepines upon saccadic eye movements in man. Clin Pharmacol Ther 12:563-574

Girdler SS, Straneva PA, Light KC, Pedersen CA, Morrow AL (2001) Allopregnanolone levels and reactivity to mental stress in premenstrual dysphoric disorder. Biol Psychiatry 49:788- 797

Glue P, White E, Wilson S, Ball DM, Nutt DJ (1991) Pharmacology of saccadic eye movements in man. 2. Effects of the alpha 2- adrenoceptor ligands idazoxan and clonidine. Psychopharmacology (Berl) 105:368-373 Gulinello M, Gong QH, Li X, Smith SS (2001) Short-term exposure to a neuroactive steroid increases alpha4 GABA(A) receptor subunit levels in association with increased anxiety in the female rat. Brain Res 910:55-66 Harrison NL, Simmonds MA (1984) Modulation of the GABA receptor complex by a steroid anaesthetic. Brain Res 323:287-292

Hill M, Parizek A, Bicikova M, Havlikova H, Klak J, Fait T, Cibula D, Hampl R, Cegan A, Sulcova J, Starka L (2000) Neuroactive steroids, their precursors, and polar conjugates during parturition and postpartum in maternal and umbilical blood: 1. Identification and simultaneous determination of pregnanolone isomers. $\mathrm{J}$ Steroid Biochem Mol Biol 75:237-244

Hill M, Bicikova M, Parizek A, Havlikova H, Klak J, Fajt T, Meloun M, Cibula D, Cegan A, Sulcova J, Hampl R, Starka L (2001) Neuroactive steroids, their precursors and polar conjugates during parturition and postpartum in maternal blood: 2. Time profiles of pregnanolone isomers. J Steroid Biochem Mol Biol 78:51-57

Hodges JK, Heistermann M, Beard A, van Aarde RJ (1997) Concentration of progesterone and the 5 alphareduced progestins, 5 alpha-pregnane-3,20-dione and 3 alpha-hydroxy-5 alphapregnan-20-one, in luteal tissue and circulating blood and their relationship to luteal function in the African elephant, Loxodonta africana. Biol Reprod 56:640-646

Holzbauer M (1976) Physiological aspects of steroids with anaesthetic properties. Med Biol 54:227-242

Hommer DW, Matsuo V, Wolkowitz O, Chrousos G, Greenblatt DJ, Weingartner H, Paul SM (1986) Benzodiazepine sensitivity in normal human subjects. Arch Gen Psychiatry 43:542-551

Lan NC, Bolger MB, Gee KW (1991) Identification and characterization of a pregnane steroid recognition site that is functionally coupled to an expressed GABAA receptor. Neurochem Res 16:347-356

Lancel M, Faulhaber J, Schiffelholz T, Romeo E, Di Michele F,

Holsboer F, Rupprecht R (1997) Allopregnanolone affects sleep in a benzodiazepine-like fashion. J Pharmacol Exp Ther 282: 1213-1218

Landgren S, Wang MD, Backstrom T, Johansson S (1998) Interaction between 3 alpha-hydroxy-5 alphapregnan-20-one and carbachol in the control of neuronal excitability in hippocampal slices of female rats in defined phases of the oestrus. Acta Physiol Scand 162:77-88 
Luisi S, Petraglia F, Benedetto C, Nappi RE, Bernardi F, Fadalti M, Reis FM, Luisi M, Genazzani AR (2000) Serum allopregnanolone levels in pregnant women: changes during pregnancy, at delivery, and in hypertensive patients. J Clin Endocrinol Metab 85:2429-2433

Majewska MD, Harrison NL, Schwartz RD, Barker JL, Paul SM (1986) Steroid hormone metabolites are barbiturate-like modulators of the GABA receptor. Science 232:1004-1007

Marshall RW, Richens A (1989) An IBM-based system for the generation, collection and analysis of saccadic and smooth pursuit eye movements. Br J Clin Pharmacol 28:752-753

Marshall RW, Griffiths AN, Richens A (1985) A microcomputer system to assess CNS depression from the analysis of the dynamics of saccadic eye movements. Br J Clin Pharmacol 20: 304-305

McCormack HM, Horne DJ, Sheather S (1988) Clinical applications of visual analogue scales: a critical review. Psychol Med 18: 1007-1019

Milewich L, Gant NF, Schwarz BE, Chen GT, MacDonald PC (1979) 5 alpha-Reductase activity in human placenta. Am J Obstet Gynecol 133:611-617

Monteleone P, Luisi S, Tonetti A, Bernardi F, Genazzani AD, Luisi M, Petraglia F, Genazzani AR (2000)

Allopregnanolone concentrations and premenstrual syndrome. Eur J Endocrinol 142: 269-273

Morrow AL, Janis GC, VanDoren MJ, Matthews DB, Samson HH. Janak PH, Grant KA (1999) Neurosteroids mediate pharmacological effects of ethanol: a new mechanism of ethanol action? Alcohol Clin Exp Res 23:1933-1940

Morrow AL, VanDoren MJ, Penland SN, Matthews DB, Fleming R, Penland S (2001) The role of GABAergic neuroactive steroids in ethanol action, tolerance and dependence. Brains Res Rev 37:98-109

Navarro PA, Kaddouz D, de Ziegler D, Silva de Sa MF, Ferriani RA (2003) Vaginal administration of allopregnanolone to postmenopausal women undergoing estrogen replacement therapy: preliminary results. Maturitas 46:147-152

Norberg L, Wahlstrom G, Backstrom T (1987) The anaesthetic potency of 3 alpha-hydroxy-5 alpha-pregnan20-one and 3 alpha- hydroxy-5 beta-pregnan-20-one determined with an intravenous EEG-threshold method in male rats. Pharmacol Toxicol 61:42-47

Nyberg S, Wahlstrom G, Backstrom T, Sundstrom Poromaa I (2004) Altered sensitivity to alcohol in the late luteal phase among patients with premenstrual dysphoric disorder. Psychoneuroendocrinology 29:767-777 Nyberg S, Andersson A, Zingmark, Wahlström G, Bäckström T, Sundström Poromaa I (2005) The effect of a low dose of alcohol on allopregnanolone serum concentrations across the menstrual cycle in women with severe premenstrual syndrome and controls. Psychoneuroendocrinology 30:892-901

Ottander U, Sundström Poromaa I, Bjurulf E, Skytt Å, Bäckström T, Olofsson JI (2005) Allopregnanolone and pregnanolone are produced by the human corpus luteum. Mol Cell Endocrinol 239(1-2):37-44

Parizek A, Hill M, Kancheva R, Havlikova H, Kancheva L, Cindr J, Paskova A, Pouzar V, Cerny I, Drbohlav P, Hajek Z, Starka L (2005) Neuroactive pregnanolone isomers during pregnancy. J Clin Endocrinol Metab 90:395-403

Pearson Murphy BE, Allison CM (2000) Determination of progesterone and some of its neuroactive ring Areduced metabolites in human serum. J Steroid Biochem Mol Biol 74:137-142 
Purdy RH, Moore PH Jr, Rao PN, Hagino N, Yamaguchi T, Schmidt P, Rubinow DR, Morrow AL, Paul SM (1990) Radioimmunoassay of 3 alpha-hydroxy-5 alpha-pregnan-20-one in rat and human plasma. Steroids $55: 290-296$

Rapkin AJ, Morgan M, Goldman L, Brann DW, Simone D, Mahesh VB (1997) Progesterone metabolite allopregnanolone in women with premenstrual syndrome. Obstet Gynecol 90:709-714

Romeo E, Strohle A, Spalletta G, di Michele F, Hermann B, Holsboer F, Pasini A, Rupprecht R (1998) Effects of antidepressant treatment on neuroactive steroids in major depression. Am J Psychiatry 155:910-913

Roy-Byrne PP, Cowley DS, Greenblatt DJ, Shader RI, Hommer D (1990) Reduced benzodiazepine sensitivity in panic disorder. Arch Gen Psychiatry 47:534-538

Schmidt PJ, Purdy RH, Moore PH Jr, Paul SM, Rubinow DR (1994) Circulating levels of anxiolytic steroids in the luteal phase in women with premenstrual syndrome and in control subjects. J Clin Endocrinol Metab 79:1256-1260

Spitzer RL, Williams JB, Kroenke K, Linzer M, deGruy FV III, Hahn SR, Brody D, Johnson JG (1994) Utility of a new procedure for diagnosing mental disorders in primary care. The PRIME-MD 1000 study. JAMA 272:1749-1756

Stoffel-Wagner B (2001) Neurosteroid metabolism in the human brain. Eur J Endocrinol 145:669-679

Strohle A, Romeo E, di Michele F, Pasini A, Yassouridis A, Holsboer F, Rupprecht R (2002) GABA(A) receptor-modulating neuroactive steroid composition in patients with panic disorder before and during paroxetine treatment. Am J Psychiatry 159:145-147

Sundstrom I, Backstrom T (1998) Patients with premenstrual syndrome have decreased saccadic eye velocity compared to control subjects. Biol Psychiatry 44:755-764

Sundstrom I, Ashbrook D, Backstrom T (1997) Reduced benzodiazepine sensitivity in patients with premenstrual syndrome: a pilot study. Psychoneuroendocrinology 22:25-38

Sundstrom I, Andersson A, Nyberg S, Ashbrook D, Purdy RH, Backstrom T (1998) Patients with premenstrual syndrome have a different sensitivity to a neuroactive steroid during the menstrual cycle compared to control subjects. Neuroendocrinology 67:126-138

Sundstrom I, Spigset O, Andersson A, Appelblad P, Backstrom T (1999) Lack of influence of menstrual cycle and premenstrual syndrome diagnosis on pregnanolone pharmacokinetics. Eur J Clin Pharmacol 55:125-130 Torres JM, Ortega E (2003) Alcohol intoxication increases allopregnanolone levels in female adolescent humans. Neuropsychopharmacology 28:1207-1209

Turkmen S, Lundgren P, Birzniece V, Zingmark E, Backstrom T, Johansson IM (2004) 3beta-20betadihydroxy-5alpha-pregnane (UC1011) antagonism of the GABA potentiation and the learning impairment induced in rats by allopregnanolone. Eur J Neurosci 20:1604-1612

Vanselow W, Dennerstein L, Greenwood KM, de Lignieres B (1996) Effect of progesterone and its 5 alpha and 5 beta metabolites on symptoms of premenstrual syndrome according to route of administration. J Psychosom Obstet Gynaecol 17:29-38

Wang M, Hammarback S, Lindhe BA, Backstrom T (1995) Treatment of premenstrual syndrome by spironolactone: a double-blind, placebo-controlled study. Acta Obstet Gynecol Scand 74:803-808 
Wang M, Seippel L, Purdy RH, Backstrom T (1996) Relationship between symptom severity and steroid variation in women with premenstrual syndrome: study on serum pregnenolone, pregnenolone sulfate, 5 alphapregnane-3,20-dione and 3 alphahydroxy- 5 alpha-pregnan-20-one. J Clin Endocrinol Metab 81:1076-1082

Wieland S, Lan NC, Mirasedeghi S, Gee KW (1991) Anxiolytic activity of the progesterone metabolite 5 alphapregnan-3 alpha-o1-20-one. Brain Res 565:263-268

Wihlback AC, Sundstrom-Poromaa I, Nyberg S, Backstrom T (2001) Sensitivity to a neurosteroid is increased during addition of progestagen to postmenopausal hormone replacement therapy. Neuroendocrinology 73:397407

Wihlback AC, Nyberg S, Backstrom T, Bixo M, Sundstrom- Poromaa I (2005) Estradiol and the addition of progesterone increase the sensitivity to a neurosteroid in postmenopausal women. Psychoneuroendocrinology $30: 38-50$

Wyatt K, Dimmock P, Jones P, Obhrai M, O’Brien S (2001) Efficacy of progesterone and progestogens in management of premenstrual syndrome: systematic review. BMJ 323:776-780

Yu R, Follesa P, Ticku MK (1996a) Down-regulation of the GABA receptor subunits mRNA levels in mammalian cultured cortical neurons following chronic neurosteroid treatment. Brain Res Mol Brain Res 41:163-168

Yu R, Hay M, Ticku MK (1996b) Chronic neurosteroid treatment attenuates single cell GABAA response and its potentiation by modulators in cortical neurons. Brain Res 706:160-162

Zhu D, Wang MD, Backstrom T, Wahlstrom G (2001) Evaluation and comparison of the pharmacokinetic and pharmacodynamic properties of allopregnanolone and pregnanolone at induction of anaesthesia in the male rat. Br J Anaesth 86:403-412

Zhu D, Birzniece V, Backstrom T, Wahlstrom G (2004) Dynamic aspects of acute tolerance to allopregnanolone evaluated using anaesthesia threshold in male rats. Br J Anaesth 93:560-567 


\section{Table 1}

Cross-reactivity test of IgY antibody from HEN1102-batch1219, titer 1/1000. as compared is to the cross-reactivity pattern from rabbit antisera obtained using the same hapten, $3 \alpha$ hydroxy-20-oxo-5 $\alpha$-pregnan-11-yl carboxymethyl ether, coupled with bovine serum albumin (Purdy et al. 1990).

\section{Cross reactivity}

Neuroactive Steroid

Hen antibody Rabbit antisera

(Agrisera) (Purdy et al.

1990)

$3 \alpha$-hydroxy-5 $\alpha$-pregnan-20one

$100 \% \quad 100 \%$

5 $\alpha$-pregnane-3,20-dione

$62 \% \quad 50 \%$

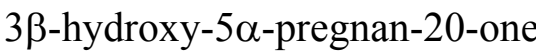

$35 \% \quad 8.3 \%$

$3 \alpha$-hydroxypregn-4-en-20-one

$32 \% \quad 50 \%$

pregnenolone

$31 \% \quad 4.0 \%$

progesterone

$17 \%$

$16.7 \%$

$3 \alpha$-hydroxy-5 $\beta$-pregnan-20-one

$16 \%$

$5.8 \%$

5 $\beta$-pregnane-3,20-dione

$12 \%$

$21.3 \%$

20 $\beta$-hydroxy-5 $\alpha$-pregnan-3-one

$<1 \%$

$13.5 \%$

$3 \beta$-hydroxy-5 $\beta$-pregnan-20-one

$<1 \% \quad<1 \%$

$20 \alpha$-hydroxypregn-4-en-3-one

$<1 \% \quad<1 \%$




\section{Table 2.}

Demographic data and physical characteristics of the study group $(n=10)$.

\section{Age (y)}

Alcohol per week (g/week)

Body mass index $\left(\mathrm{kg} / \mathrm{m}^{2}\right)$

Married (\%)

Children (n)

Menstrual cycle length (days)

Use of hormonal anticonceptives (\%)

Tobacco users $(\%)$

Education, university/college (\%)

Employed/studying (\%)
$25.0 \pm 1.3$

$$
35.9 \pm 7.3
$$

$21.6 \pm 0.6$

$2(20 \%)$

$0.3 \pm 0.2$

$29.4 \pm 0.8$

0

$4(40 \%)$

$8(80 \%)$

$10(100 \%)$

Data are presented as mean \pm standard error of the mean or $n(\%)$. 


\section{Table 3}

Pharmacokinetic parameters of allopregnanolone after three injections, representing a cumulative dose of $0.09 \mathrm{mg} / \mathrm{kg}$ allopregnanolone, to 10 patients in the follicular phase of the menstrual cycle.

\begin{tabular}{lc}
\hline & Healthy women $(\mathrm{n}=10)$ \\
& Mean $\pm \mathrm{SD}$ \\
\hline $\mathrm{C}_{0}\left(\mathrm{nmol} \cdot 1^{-1}\right)$ & $0.46 \pm 0.2$ \\
$\mathrm{C}_{5}\left(\mathrm{nmol} \cdot 1^{-1}\right)$ & $20.9 \pm 9.7$ \\
$\mathrm{C}_{35}\left(\mathrm{nmol} \cdot 1^{-1}\right)$ & $52.9 \pm 26.2$ \\
$\mathrm{C}_{65}\left(\mathrm{nmol} \cdot \mathrm{l}^{-1}\right)$ & $71.8 \pm 29.0$ \\
$\mathrm{t}_{1 / 2,1}(\mathrm{~min})$ & $43.9 \pm 7.3$ \\
$\mathrm{t}_{1 / 2, \mathrm{z}}(\mathrm{min})$ & $261 \pm 100$ \\
$\mathrm{AUC}\left(\mathrm{nmol} \cdot \mathrm{l}^{-1} \cdot \min \right)$ & $8897 \pm 1467$ \\
$\mathrm{CL}\left(\mathrm{ml} \cdot \mathrm{min}^{-1} \cdot \mathrm{kg}^{-1}\right)$ & $32.6 \pm 5.8$ \\
$\mathrm{~V}_{\mathrm{z}}\left(\mathrm{l} \cdot \mathrm{kg}^{-1}\right)$ & $12.5 \pm 6.3$ \\
$\mathrm{~V}_{\mathrm{ss}}\left(\mathrm{l} \cdot \mathrm{kg}^{-1}\right)$ & $7.3 \pm 2.5$ \\
\hline
\end{tabular}

$\mathrm{C}_{0}$ endogenous serum concentration; $\mathrm{C}_{5}, \mathrm{C}_{35}, \mathrm{C}_{65}$ serum concentrations at 5 minutes after each allopregnanolone injection; $t_{1 / 2,1}$ distribution phase half-life; $t_{1 / 2,2}$ elimination phase halflife; AUC, area under the serum concentration/time curve; $\mathrm{CL}$, clearance; $\mathrm{V}_{\mathrm{z}}$, Volume of distribution in the elimination phase; $\mathrm{V}_{\mathrm{ss}}$, Volume of distribution at steady state. 
Figure 1

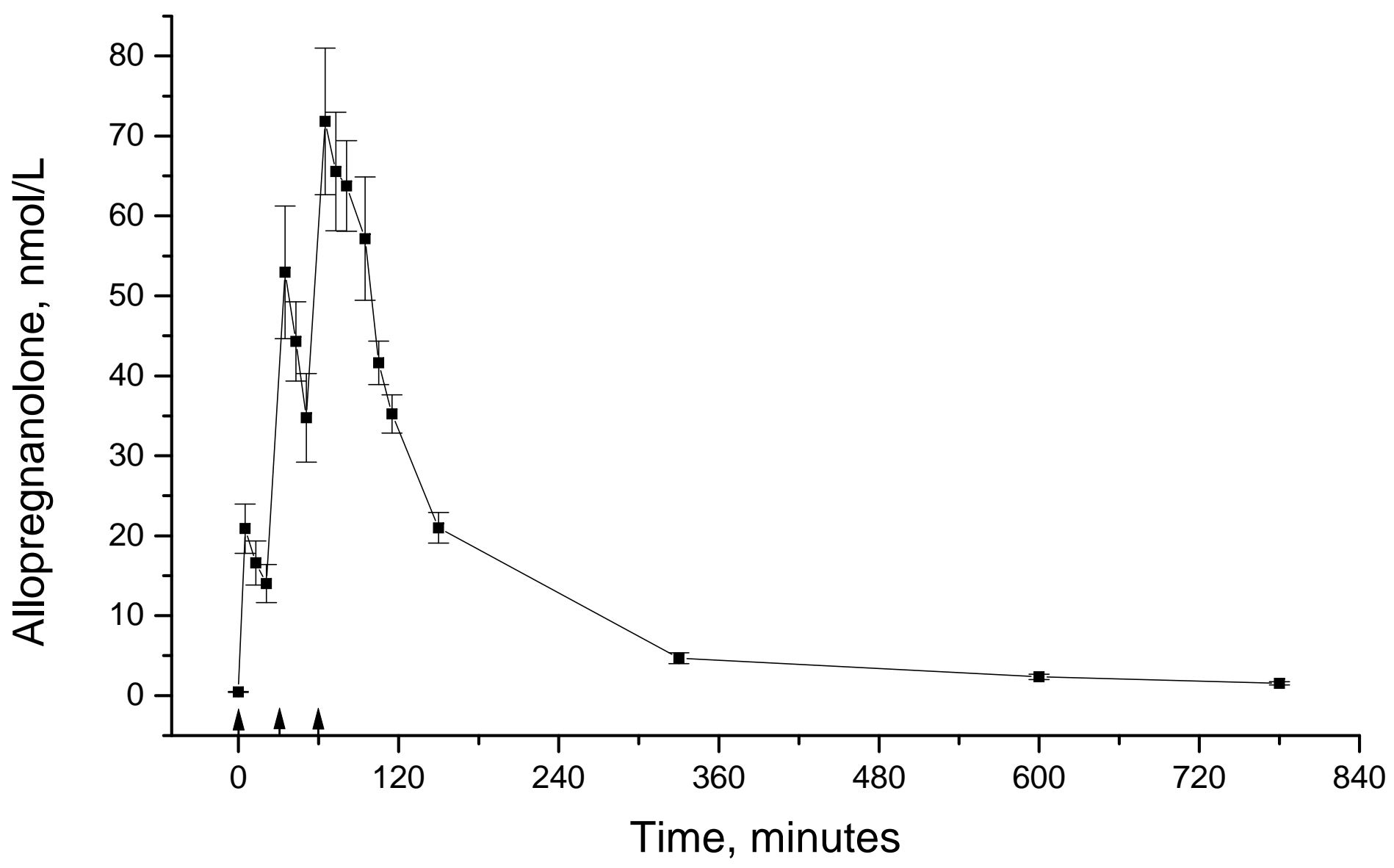


Figure 2
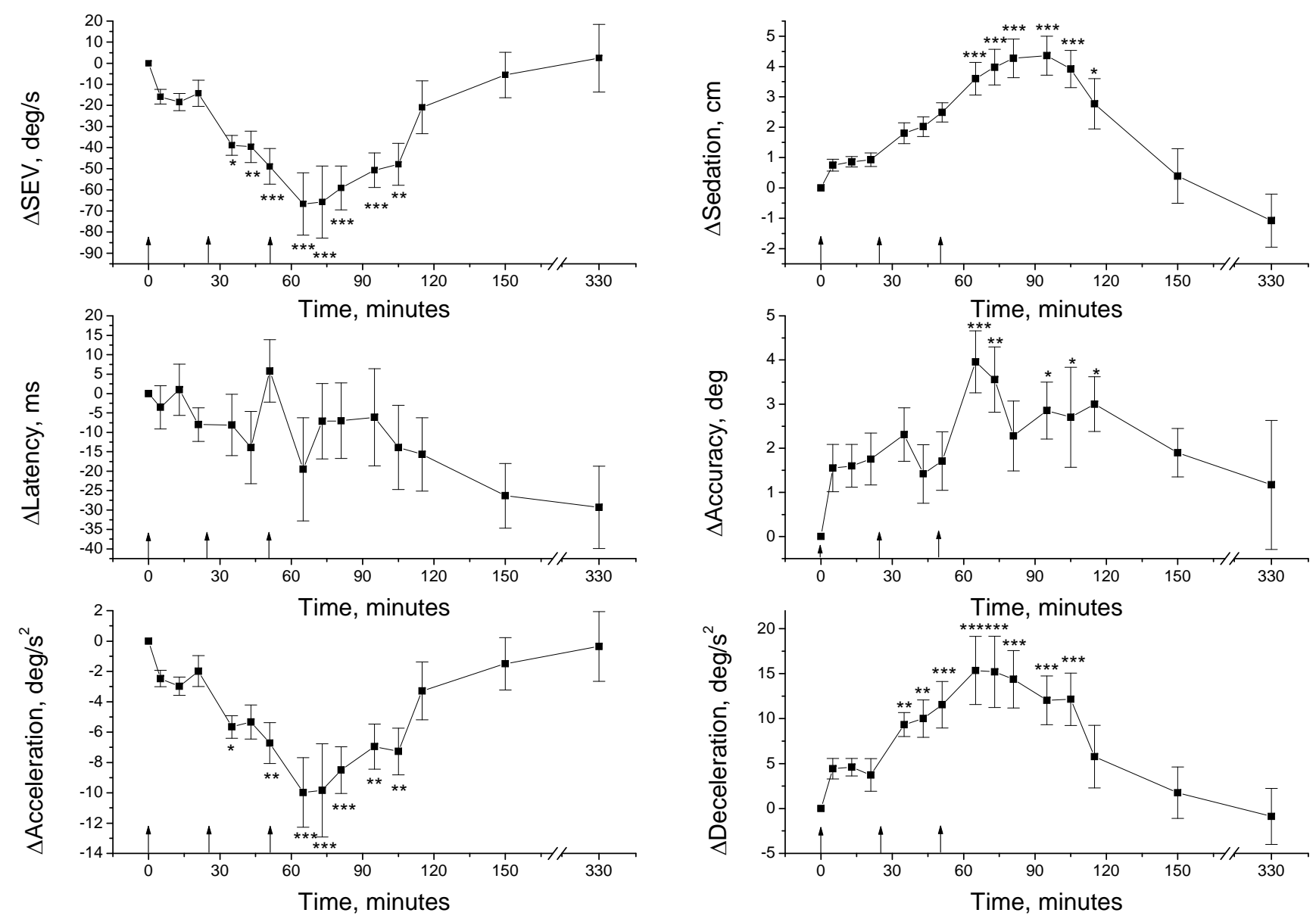
Figure 3

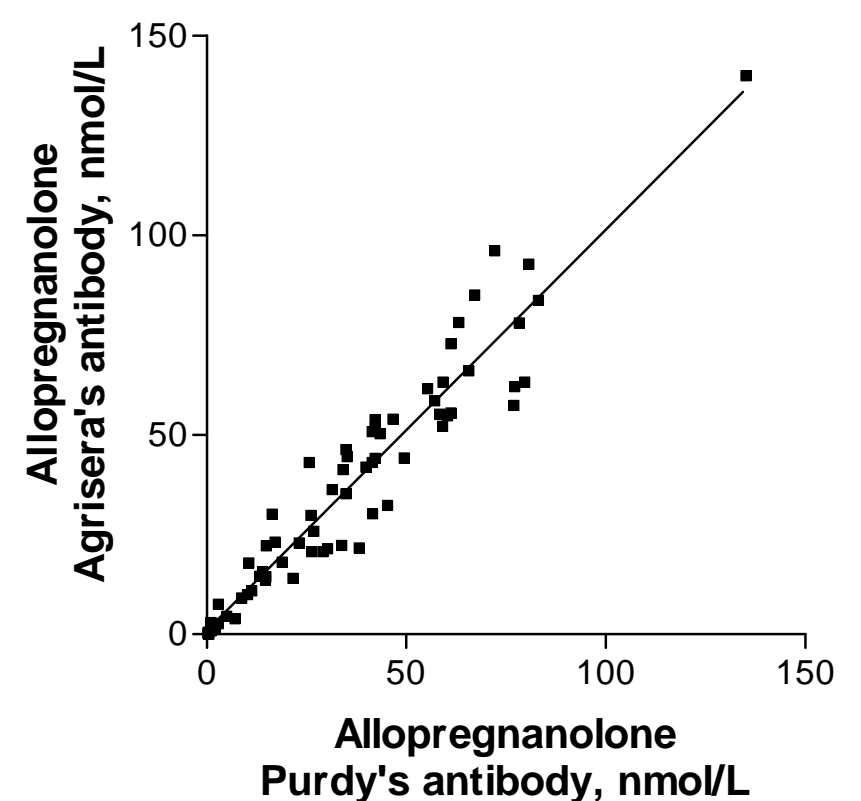




\section{Legends}

Figure 1

Serum concentration-time profile of allopregnanolone in the follicular phase of the menstrual cycle, values given as mean \pm SEM., $n=10$. Doses of allopregnanolone were $0.015,0.03$, and $0.045 \mathrm{mg} / \mathrm{kg}$, and are indicated by arrows. The polyclonal rabbit antiserum was used for determination of allopregnanolone serum concentrations.

\section{Figure 2}

Allopregnanolone effect on saccade parameters and sedation scores were evaluated in 10 healthy women during the follicular phase of the menstrual cycle. Mean \pm SEM of the change in saccadic eye velocity, saccade acceleration, saccade deceleration, saccade latency, saccade accuracy and visual analogue scores of sedation during the allopregnanolone challenge. During a saccade the eye velocity rises and falls smoothly, why maximum acceleration and maximum deceleration can be determined. Latency is the time lapse between the target movement to the onset of a saccade. Saccade accuracy is determined by comparing the actual eye position at the end of the saccade with the attempted target. $* \mathrm{p}<0.05$, Tukey Honestly Significance Test, ${ }^{* *} \mathrm{p}<0.01$, Tukey Honestly Significance Test, ${ }^{* * *} \mathrm{p}<0.001$, Tukey Honestly Significance Test

Figure 3

Allopregnanolone, $\mathrm{nmol} / \mathrm{L}$, measured in serum samples from women during the follicular phase of menstrual cycle after iv injections of allopregnanolone $0.015,0.03$, and $0.045 \mathrm{mg} / \mathrm{kg}$, respectively $(n=77)$. After celite chromatography separation, the serum samples were assayed with both a polyclonal rabbit antisera (Purdy et al. 1990) and the recently prepared 
hen IgY antibody (Hen1102, Agrisera AB, Vännäs, Sweden). The correlation coefficient was $\mathrm{r}=0.962 ; \mathrm{p}<0.001$. The equation for the regression line was AlloAgrisera $=0.896+1.005 \mathrm{x}$ AlloPurdy, $F(1,75)=937 ; p<0.001$. The confidence limits of the line slope were 0.940 to 1.071 and the line broke the $\mathrm{Y}$-axis at $0.896 \mathrm{nmol} / \mathrm{L}, 95 \%$ confidence interval -1.89 to 3.68 , which is not different from zero. 


\section{References}

Andreen L, Sundstrom-Poromaa I, Bixo M, Andersson A, Nyberg S, Backstrom T (2005) Relationship between allopregnanolone and negative mood in postmenopausal women taking sequential hormone replacement therapy with vaginal progesterone. Psychoneuroendocrinology 30:212-224

Backstrom T, Andersson A, Baird DT, Selstam G (1986) The human corpus luteum secretes 5 alpha-pregnane3,20-dione. Acta Endocrinol (Copenh) 111:116-121

Baloh RW, Sills AW, Kumley WE, Honrubia V (1975) Quantitative measurement of saccade amplitude, duration, and velocity. Neurology 25:1065-1070

Beauchamp MH, Ormerod BK, Jhamandas K, Boegman RJ, Beninger RJ (2000) Neurosteroids and reward: allopregnanolone produces a conditioned place aversion in rats. Pharmacol Biochem Behav 67:29-35

Bicikova M, Dibbelt L, Hill M, Hampl R, Starka L (1998) Allopregnanolone in women with premenstrual syndrome. Horm Metab Res 30:227-230

Bicikova M, Tallova J, Hill M, Krausova Z, Hampl R (2000) Serum concentrations of some neuroactive steroids in women suffering from mixed anxiety-depressive disorder. Neurochem Res 25:1623-1627

Bitran D, Hilvers RJ, Kellogg CK (1991) Anxiolytic effects of 3 alpha-hydroxy-5 alpha[beta]-pregnan-20-one: endogenous metabolites of progesterone that are active at the GABAA receptor. Brain Res 561:157-161

Bitran D, Shiekh M, McLeod M (1995) Anxiolytic effect of progesterone is mediated by the neurosteroid allopregnanolone at brain GABAA receptors. J Neuroendocrinol 7:171-177

Bitran D, Dugan M, Renda P, Ellis R, Foley M (1999) Anxiolytic effects of the neuroactive steroid pregnanolone (3 alpha-OH-5 beta-pregnan-20-one) after microinjection in the dorsal hippocampus and lateral septum. Brain Res 850:217-224

Carl P, Hogskilde S, Nielsen JW, Sorensen MB, Lindholm M, Karlen B, Backstrom T (1990) Pregnanolone emulsion. A preliminary pharmacokinetic and pharmacodynamic study of a new intravenous anaesthetic agent. Anaesthesia 45:189-197

Carl P, Hogskilde S, Lang-Jensen T, Bach V, Jacobsen J, Sorensen MB, Gralls M, Widlund L (1994)

Pharmacokinetics and pharmacodynamics of eltanolone (pregnanolone), a new steroid intravenous anaesthetic, in humans. Acta Anaesthesiol Scand 38:734-741

de Lignieres B, Dennerstein L, Backstrom T (1995) Influence of route of administration on progesterone metabolism. Maturitas 21:251-257

Epperson CN, Haga K, Mason GF, Sellers E, Gueorguieva R, Zhang W, Weiss E, Rothman DL, Krystal JH (2002) Cortical gammaaminobutyric acid levels across the menstrual cycle in healthy women and those with premenstrual dysphoric disorder: a proton magnetic resonance spectroscopy study. Arch Gen Psychiatry 59:851858

Finn DA, Phillips TJ, Okorn DM, Chester JA, Cunningham CL (1997) Rewarding effect of the neuroactive steroid 3 alphahydroxy-5 alpha-pregnan-20-one in mice. Pharmacol Biochem Behav 56:261-264

Freeman EW, Purdy RH, Coutifaris C, Rickels K, Paul SM (1993) Anxiolytic metabolites of progesterone: correlation with mood and performance measures following oral progesterone administration to healthy female volunteers. Neuroendocrinology 58: 478-484 
Friedman L, Gibbs TT, Farb DH (1993) Gamma-aminobutyric acidA receptor regulation: chronic treatment with pregnanolone uncouples allosteric interactions between steroid and benzodiazepine recognition sites. Mol Pharmacol 44:191-197

Gee KW, McCauley LD, Lan NC (1995) A putative receptor for neurosteroids on the GABAA receptor complex: the pharmacological properties and therapeutic potential of epalons. Crit Rev Neurobiol 9:207-227

Genazzani AR, Petraglia F, Bernardi F, Casarosa E, Salvestroni C, Tonetti A, Nappi RE, Luisi S, Palumbo M, Purdy RH, Luisi M (1998) Circulating levels of allopregnanolone in humans: gender, age, and endocrine influences. J Clin Endocrinol Metab 83:2099-2103

Gentles W, Thomas EL (1971) Commentary. Effect of benzodiazepines upon saccadic eye movements in man. Clin Pharmacol Ther 12:563-574

Girdler SS, Straneva PA, Light KC, Pedersen CA, Morrow AL (2001) Allopregnanolone levels and reactivity to mental stress in premenstrual dysphoric disorder. Biol Psychiatry 49:788- 797

Glue P, White E, Wilson S, Ball DM, Nutt DJ (1991) Pharmacology of saccadic eye movements in man. 2. Effects of the alpha 2- adrenoceptor ligands idazoxan and clonidine. Psychopharmacology (Berl) 105:368-373 Gulinello M, Gong QH, Li X, Smith SS (2001) Short-term exposure to a neuroactive steroid increases alpha4 GABA(A) receptor subunit levels in association with increased anxiety in the female rat. Brain Res 910:55-66

Harrison NL, Simmonds MA (1984) Modulation of the GABA receptor complex by a steroid anaesthetic. Brain Res 323:287-292

Hill M, Parizek A, Bicikova M, Havlikova H, Klak J, Fait T, Cibula D, Hampl R, Cegan A, Sulcova J, Starka L (2000) Neuroactive steroids, their precursors, and polar conjugates during parturition and postpartum in maternal and umbilical blood: 1. Identification and simultaneous determination of pregnanolone isomers. J Steroid Biochem Mol Biol 75:237-244

Hill M, Bicikova M, Parizek A, Havlikova H, Klak J, Fajt T, Meloun M, Cibula D, Cegan A, Sulcova J, Hampl R, Starka L (2001) Neuroactive steroids, their precursors and polar conjugates during parturition and postpartum in maternal blood: 2. Time profiles of pregnanolone isomers. J Steroid Biochem Mol Biol 78:51-57

Hodges JK, Heistermann M, Beard A, van Aarde RJ (1997) Concentration of progesterone and the 5 alphareduced progestins, 5 alpha-pregnane-3,20-dione and 3 alpha-hydroxy-5 alphapregnan-20-one, in luteal tissue and circulating blood and their relationship to luteal function in the African elephant, Loxodonta africana. Biol Reprod 56:640-646

Holzbauer M (1976) Physiological aspects of steroids with anaesthetic properties. Med Biol 54:227-242

Hommer DW, Matsuo V, Wolkowitz O, Chrousos G, Greenblatt DJ, Weingartner H, Paul SM (1986)

Benzodiazepine sensitivity in normal human subjects. Arch Gen Psychiatry 43:542-551

Lan NC, Bolger MB, Gee KW (1991) Identification and characterization of a pregnane steroid recognition site that is functionally coupled to an expressed GABAA receptor. Neurochem Res 16:347-356

Lancel M, Faulhaber J, Schiffelholz T, Romeo E, Di Michele F,

Holsboer F, Rupprecht R (1997) Allopregnanolone affects sleep in a benzodiazepine-like fashion. J Pharmacol Exp Ther 282: 1213-1218

Landgren S, Wang MD, Backstrom T, Johansson S (1998) Interaction between 3 alpha-hydroxy-5 alphapregnan-20-one and carbachol in the control of neuronal excitability in hippocampal slices of female rats in defined phases of the oestrus. Acta Physiol Scand 162:77-88 
Luisi S, Petraglia F, Benedetto C, Nappi RE, Bernardi F, Fadalti M, Reis FM, Luisi M, Genazzani AR (2000) Serum allopregnanolone levels in pregnant women: changes during pregnancy, at delivery, and in hypertensive patients. J Clin Endocrinol Metab 85:2429-2433

Majewska MD, Harrison NL, Schwartz RD, Barker JL, Paul SM (1986) Steroid hormone metabolites are barbiturate-like modulators of the GABA receptor. Science 232:1004-1007

Marshall RW, Richens A (1989) An IBM-based system for the generation, collection and analysis of saccadic and smooth pursuit eye movements. Br J Clin Pharmacol 28:752-753

Marshall RW, Griffiths AN, Richens A (1985) A microcomputer system to assess CNS depression from the analysis of the dynamics of saccadic eye movements. Br J Clin Pharmacol 20: 304-305

McCormack HM, Horne DJ, Sheather S (1988) Clinical applications of visual analogue scales: a critical review. Psychol Med 18: 1007-1019

Milewich L, Gant NF, Schwarz BE, Chen GT, MacDonald PC (1979) 5 alpha-Reductase activity in human placenta. Am J Obstet Gynecol 133:611-617

Monteleone P, Luisi S, Tonetti A, Bernardi F, Genazzani AD, Luisi M, Petraglia F, Genazzani AR (2000)

Allopregnanolone concentrations and premenstrual syndrome. Eur J Endocrinol 142: 269-273

Morrow AL, Janis GC, VanDoren MJ, Matthews DB, Samson HH. Janak PH, Grant KA (1999) Neurosteroids mediate pharmacological effects of ethanol: a new mechanism of ethanol action? Alcohol Clin Exp Res 23:1933-1940

Morrow AL, VanDoren MJ, Penland SN, Matthews DB, Fleming R, Penland S (2001) The role of GABAergic neuroactive steroids in ethanol action, tolerance and dependence. Brains Res Rev 37:98-109

Navarro PA, Kaddouz D, de Ziegler D, Silva de Sa MF, Ferriani RA (2003) Vaginal administration of allopregnanolone to postmenopausal women undergoing estrogen replacement therapy: preliminary results. Maturitas 46:147-152

Norberg L, Wahlstrom G, Backstrom T (1987) The anaesthetic potency of 3 alpha-hydroxy-5 alpha-pregnan-20one and 3 alpha- hydroxy-5 beta-pregnan-20-one determined with an intravenous EEG-threshold method in male rats. Pharmacol Toxicol 61:42-47

Nyberg S, Wahlstrom G, Backstrom T, Sundstrom Poromaa I (2004) Altered sensitivity to alcohol in the late luteal phase among patients with premenstrual dysphoric disorder. Psychoneuroendocrinology 29:767-777 Nyberg S, Andersson A, Zingmark, Wahlström G, Bäckström T, Sundström Poromaa I (2005) The effect of a low dose of alcohol on allopregnanolone serum concentrations across the menstrual cycle in women with severe premenstrual syndrome and controls. Psychoneuroendocrinology 30:892-901

Ottander U, Sundström Poromaa I, Bjurulf E, Skytt A, Bäckström T, Olofsson JI (2005) Allopregnanolone and pregnanolone are produced by the human corpus luteum. Mol Cell Endocrinol 239(1-2):37-44

Parizek A, Hill M, Kancheva R, Havlikova H, Kancheva L, Cindr J, Paskova A, Pouzar V, Cerny I, Drbohlav P, Hajek Z, Starka L (2005) Neuroactive pregnanolone isomers during pregnancy. J Clin Endocrinol Metab 90:395-403

Pearson Murphy BE, Allison CM (2000) Determination of progesterone and some of its neuroactive ring Areduced metabolites in human serum. J Steroid Biochem Mol Biol 74:137-142 
Purdy RH, Moore PH Jr, Rao PN, Hagino N, Yamaguchi T, Schmidt P, Rubinow DR, Morrow AL, Paul SM (1990) Radioimmunoassay of 3 alpha-hydroxy-5 alpha-pregnan-20-one in rat and human plasma. Steroids 55:290-296

Rapkin AJ, Morgan M, Goldman L, Brann DW, Simone D, Mahesh VB (1997) Progesterone metabolite allopregnanolone in women with premenstrual syndrome. Obstet Gynecol 90:709-714

Romeo E, Strohle A, Spalletta G, di Michele F, Hermann B, Holsboer F, Pasini A, Rupprecht R (1998) Effects of antidepressant treatment on neuroactive steroids in major depression. Am J Psychiatry 155:910-913

Roy-Byrne PP, Cowley DS, Greenblatt DJ, Shader RI, Hommer D (1990) Reduced benzodiazepine sensitivity in panic disorder. Arch Gen Psychiatry 47:534-538

Schmidt PJ, Purdy RH, Moore PH Jr, Paul SM, Rubinow DR (1994) Circulating levels of anxiolytic steroids in the luteal phase in women with premenstrual syndrome and in control subjects. J Clin Endocrinol Metab 79:1256-1260

Spitzer RL, Williams JB, Kroenke K, Linzer M, deGruy FV III, Hahn SR, Brody D, Johnson JG (1994) Utility of a new procedure for diagnosing mental disorders in primary care. The PRIME-MD 1000 study. JAMA 272:1749-1756

Stoffel-Wagner B (2001) Neurosteroid metabolism in the human brain. Eur J Endocrinol 145:669-679

Strohle A, Romeo E, di Michele F, Pasini A, Yassouridis A, Holsboer F, Rupprecht R (2002) GABA(A) receptor-modulating neuroactive steroid composition in patients with panic disorder before and during paroxetine treatment. Am J Psychiatry 159:145-147

Sundstrom I, Backstrom T (1998) Patients with premenstrual syndrome have decreased saccadic eye velocity compared to control subjects. Biol Psychiatry 44:755-764

Sundstrom I, Ashbrook D, Backstrom T (1997) Reduced benzodiazepine sensitivity in patients with premenstrual syndrome: a pilot study. Psychoneuroendocrinology 22:25-38

Sundstrom I, Andersson A, Nyberg S, Ashbrook D, Purdy RH, Backstrom T (1998) Patients with premenstrual syndrome have a different sensitivity to a neuroactive steroid during the menstrual cycle compared to control subjects. Neuroendocrinology 67:126-138

Sundstrom I, Spigset O, Andersson A, Appelblad P, Backstrom T (1999) Lack of influence of menstrual cycle and premenstrual syndrome diagnosis on pregnanolone pharmacokinetics. Eur J Clin Pharmacol 55:125-130 Torres JM, Ortega E (2003) Alcohol intoxication increases allopregnanolone levels in female adolescent humans. Neuropsychopharmacology 28:1207-1209

Turkmen S, Lundgren P, Birzniece V, Zingmark E, Backstrom T, Johansson IM (2004) 3beta-20betadihydroxy-5alpha-pregnane (UC1011) antagonism of the GABA potentiation and the learning impairment induced in rats by allopregnanolone. Eur J Neurosci 20:1604-1612

Vanselow W, Dennerstein L, Greenwood KM, de Lignieres B (1996) Effect of progesterone and its 5 alpha and 5 beta metabolites on symptoms of premenstrual syndrome according to route of administration. J Psychosom Obstet Gynaecol 17:29-38

Wang M, Hammarback S, Lindhe BA, Backstrom T (1995) Treatment of premenstrual syndrome by spironolactone: a double-blind, placebo-controlled study. Acta Obstet Gynecol Scand 74:803-808 
Wang M, Seippel L, Purdy RH, Backstrom T (1996) Relationship between symptom severity and steroid variation in women with premenstrual syndrome: study on serum pregnenolone, pregnenolone sulfate, 5 alphapregnane-3,20-dione and 3 alphahydroxy- 5 alpha-pregnan-20-one. J Clin Endocrinol Metab 81:1076-1082

Wieland S, Lan NC, Mirasedeghi S, Gee KW (1991) Anxiolytic activity of the progesterone metabolite 5 alphapregnan-3 alpha-o1-20-one. Brain Res 565:263-268

Wihlback AC, Sundstrom-Poromaa I, Nyberg S, Backstrom T (2001) Sensitivity to a neurosteroid is increased during addition of progestagen to postmenopausal hormone replacement therapy. Neuroendocrinology 73:397407

Wihlback AC, Nyberg S, Backstrom T, Bixo M, Sundstrom- Poromaa I (2005) Estradiol and the addition of progesterone increase the sensitivity to a neurosteroid in postmenopausal women. Psychoneuroendocrinology 30:38-50

Wyatt K, Dimmock P, Jones P, Obhrai M, O’Brien S (2001) Efficacy of progesterone and progestogens in management of premenstrual syndrome: systematic review. BMJ 323:776-780

Yu R, Follesa P, Ticku MK (1996a) Down-regulation of the GABA receptor subunits mRNA levels in mammalian cultured cortical neurons following chronic neurosteroid treatment. Brain Res Mol Brain Res 41:163-168

Yu R, Hay M, Ticku MK (1996b) Chronic neurosteroid treatment attenuates single cell GABAA response and its potentiation by modulators in cortical neurons. Brain Res 706:160-162

Zhu D, Wang MD, Backstrom T, Wahlstrom G (2001) Evaluation and comparison of the pharmacokinetic and pharmacodynamic properties of allopregnanolone and pregnanolone at induction of anaesthesia in the male rat. Br J Anaesth 86:403-412

Zhu D, Birzniece V, Backstrom T, Wahlstrom G (2004) Dynamic aspects of acute tolerance to allopregnanolone evaluated using anaesthesia threshold in male rats. Br J Anaesth 93:560-567 